\title{
The Effectiveness of the Dealing with Homophobia Psycho-Education Program on Psychological Counselor Candidates
}

\author{
Meryem Vural-Batık ${ }^{1}$ \\ ${ }^{1}$ Faculty of Education, Ondokuz Mayis University, Samsun, Turkey \\ Correspondence: Meryem Vural-Batık, Faculty of Education, Ondokuz Mayıs University, Samsun, Turkey. Tel: \\ 90-0362-3121919-5515. E-mail: meryem.vural@ omu.edu.tr
}

Received: April 17, 2020

Accepted: May 8, 2020 Online Published: May 15, 2020

doi:10.5539/hes.v10n3p1

URL: https://doi.org/10.5539/hes.v10n3p1

\begin{abstract}
The aim of this research is to investigate the effect of the Dealing with Homophobia Psycho-Education Program on homophobia levels of psychological counselor candidates. This research was conducted with a mixed model and utilized quantitative and qualitative methods. 2 (experimental and control groups) x 3 (pre-test, post-test, follow-up) research design which is a type of quasi-experimental design was used and content analysis was applied to the data obtained via interviews. The study was conducted with a total of 24 psychological counselor candidates, 12 in the experimental group and, 12 in the control group. The Homophobia Scale was used to determine the homophobia levels of psychological counselor candidates. The Dealing with Homophobia Psycho-Education Program was developed by the researcher. In order to determine the effectiveness of the program, The Two-Way Analysis of Variance with Repeated Measures was used. As a result of the research, it was determined that the Dealing with Homophobia Psycho-Education Program is effective in decreasing the levels of homophobia of the psychological counselor candidates. Also, according to the participant's views, it was determined that the psycho-education program was effective in decreasing homophobia and caused changes in attitudes. The importance and necessity of using the program on psychological counselor education are discussed.
\end{abstract}

Keywords: homosexual, LGBT, psychological counselor, multicultural counseling, counselor education

\section{Introduction}

Sexual identity can be defined as the perception of oneself and his/her body within a certain gender; sexual orientation can be described as an enduring sexual, emotional, affectional, or behavioural attraction to individuals of a particular gender, and sexual role can be defined as the expression of sexual behaviors within the society (Yüksel, 2010). Sexual minorities have a greater risk of psychological problems compared to heterosexual individuals (Bostwick, Boyd, Hughes, \& McCabe, 2010; Kaysen et al., 2014). When the related literature is examined, it is seen that lesbian, gay, bisexual and transexuel (LGBT) students are more likely to have suicide ideation compared to their same-aged peers (Bouris, Everett, Heath, Elsaesser, \& Neilands, 2016; Dunn, Clark, \& Pearlman, 2015). In addition, LGBT students are experiencing more social isolation due to negative experiences such as exclusion, derision and bullying (Button, O'Connell, \& Gealt, 2012; Henderson, 2016) and are more absent from school (Bouris et al., 2016; Burton, Marshal, \& Chisolm, 2014). It can be said that attitudes of heterosexual individuals are the reason for these difficulties that LGBT individuals face.

Several studies in the previous literature have examined the attitudes toward homosexual people (Elipe, Oliva Muñoz, \& Del Rey, 2018; Meydan-Acımış \& Tekindal, 2013; Nelson \& Krieger, 1997; Sakallı, 2002a, 2002b; Santona \& Tognasso, 2018; Saraç, 2012; Sargın \& C1rcır, 2015; Thatcher \& Chandler, 2013; Ummak, 2012;) and have reported that these attitudes are negative. Homophobia is generally defined as negative emotions, attitudes and/or behaviors towards people with different sexual orientations or identities such as homosexuality, bisexuality, and transsexuality (Budak, 2003). LBGT individuals who do not behave appropriately to social gender roles that are expected are exposed to more violence and harassment in the society (Butler, 2010), and homophobia is an important cause of violence and aggression against homosexuals (Orue \& Calvete, 2018). In many countries, LGBT individuals are being killed, rehabilitated, ignored, assimilated, discriminated, restricted, and their process of self-identification is prevented due to the homophobia (Selek, 2003). Even it is stated that homophobic bullying is one of the most common forms of bullying (Guasp, 2009). Taking into account the 
negative effects of homophobic bullying that LGBT students are exposed to (Murdock \& Bolch, 2005), the intervention of teachers to prevent this kind of bullying is tremendously important.

School counselors, as well as teachers, play a critical role in the negative experiences that LGBT students experience in both school and personal life and social environments. But school counselors do not have adequate psychological counseling/therapy training to gain competencies to help homosexuals in Turkey. In this regard, it is suggested that programs developed to deal with homophobia should also be used in psychological counseling education. It is thought that if the school counselors are educated and trained to discuss and defend LGBT issues, they can be more courageous to talk about homophobic attitudes, behaviors, and discourses and to influence student awareness. The trained school counselor will be able to share the correct information about the sexual identity and sexual orientation with the teachers and co-ordinate intervention programs that focus on homophobia (Ummak \& Gündoğdu, 2014). Similarly, the Turkish Psychiatric Association (TPA) and Sexual Education Treatment and Research Association held a press conference in 2015, and stated that educational administrators must consider of the physical and psychological developments of homosexual students immediately. However, it was emphasized that educators should be a guide for these young people instead of being a strict advocate of traditional norms. In addition, it is stated that if educators are not knowledgeable and sensitive about LGBT, they will not be able to provide a safe educational environment for these individuals and the homophobic attitudes towards these individuals cannot change (TPA, 2015). Gegenfurtner and Gebhardt (2017) noted that teachers are role models for other students in sexual education in schools, and their reactions and attitudes about discussing LGBT issues in their classroom may be examples for students. At this point, it is thought that it is important to determine the educators' prejudices and misconceptions about sexual diversity, and then to support them to help students to struggle with sexual identity and to create a comprehensive educational environment and they educators should be educated about coping effectively with homophobic attitudes and bullying. Developing and implementing intervention programs that aim to reduce prejudice and educating people about discrimination against sexual diversity may be useful against harassments related to sexual orientation in school settings (Ferfolja, 2008). Similarly, it is emphasized that the delivery of accurate information about LGBT to teachers and psychological counselors should be a part of the preventive mental health services (TPA, 2015).

In short, it is necessary to reduce homophobic attitudes and behaviors of psychological counselors so that psychological counselors can both provide effective counseling services for homosexual individuals and become role models for their peers. In this context, it is thought that implementing psycho-education programs to reduce homophobic attitudes of psychological counselors is very important. There are several programs aimed to deal with homophobia in other countries (Ben-Ari, 1998; Case \& Stewart, 2010; Cooley \& Burkholder, 2011; Engberg, Hurtado, \& Smith, 2005; Foreman \& Quinlan, 2008; GLSEN, 1999; Higgins, King, \& Witthaus, 2001; Kelley, Chou, Dibble, \& Robertson, 2008; Ollis, 2010; Nelson \& Krieger, 1997; Riggs, Rosenthal, \& Smith-Bonahue, 2011; Rudolph, 1989; Sakallı \& Uğurlu, 2001, 2003). In Turkey, there is a study that applied to the teachers of the program dealing with homophobia. In the study, it was observed that the program applied to teachers reduced the homophobia attitudes of teachers and this effect was long-term (Ummak, 2016). In this context, it is thought that psychological counselors and psychological counselor candidates need to be informed about sexual orientation and sexual identity and thus psycho-education programs should be developed for gaining intervention skills for discrimination.

This study was conducted to investigate the effect of dealing with homophobia psycho-education program on homophobia levels of psychological counselor candidates. In this direction, the following questions were answered:

1. Is the dealing with homophobia psycho-education program effective to reduce the homophobia levels of psychological counselor candidates?

2. If the dealing with homophobia psycho-education program is effective to reduce the homophobia, is this effect long-term?

3. What are the opinions of psychological counselor candidates about the effectiveness of dealing with homophobia psycho-education program?

\section{Method}

\subsection{Research Design}

This study, which examined the effect of the dealing with homophobia psycho-education program applied to the psychological counselor candidates, was conducted with a mixed model and utilized quantitative and qualitative methods. The qualitative dimension of this study consists of the opinions of the psychological counselor 
candidates participating in the dealing with homophobia psycho-education program on the effectiveness of the program. The quantitative dimension of the study consists of the examination of whether the homophobia levels of the psychological counselor candidates who participated in the dealing with psycho-education program differed significantly. In this direction, "2 (experimental and control groups) x 3 (pre-test, post-test, follow-up) research design" which is a type of quasi-experimental design was used. The quasi-experimental design is the most commonly used experimental design when it is not possible to control all variables, especially in the field of education (Cohen, Manion, \& Marrison, 2000). The research design is presented in Table 1.

Table 1. Research design

\begin{tabular}{llllll}
\hline Groups & Pre-test & Intervention & Post-test & Intervention & Follow-up test \\
\hline Experimental Group & HS* & Psycho-Education Program & HS & ------- & HS \\
Control Group & HS & ------- & HS & ------- & HS \\
\hline
\end{tabular}

*HS: The Homophobia Scale

The current study was conducted with the ethical permission of the Research Ethics Committee of Social and Human Sciences. In the study pre-test data were collected from the experimental and control groups through the Homophobia Scale (HS). Then, an eight-session the dealing with homophobia psycho-education program was administrated to the experiment group. Any intervention was applied to the control group. After the intervention, the Homophobia scale was administrated to the experimental and control group as a post-test. One month after the last test, both groups were applied to the same scale and the follow-up data were collected. The research has an independent and dependent variable. The independent variable of the research is "Psycho-Educational Program to Deal with Homophobia", and the dependent variable is the level of homophobia measured by the Homophobia Scale.

\subsection{Participants}

The participants of the study consist of last year students who are studying in the department of guidance and psychological counseling in a state university. Firstly, the Homophobia Scale was administered to the psychological counseling candidates and the students with high homophobia according to the scores obtained from scale were determined. In order to form two groups (experimental and control) the scores that psychological counselor candidates obtained from the scale and other demographic characteristics were taken into consideration. The researcher used one to one correspondence method to form the groups and 24 participants were divided into two groups. In order to form these groups of researchers who have an experiment and a control group, a 12-person experiment and a 12-person control group was established by using the self-replicating method, taking into consideration scores and other demographic characteristics of the psychological counselor candidates. A total of 24 participants were assigned to the experimental and control groups (12 in the experimental group and 12 in the control group).

The average age of participants in the experimental group was $\mathrm{M}=22.4(\mathrm{SD}=.99)$ and the average age of participants in the control group was $\mathrm{M}=22.2$ ( $\mathrm{SD}=.62$ ). Distribution of participants in terms of gender was equal. There were 7 females and 5 males in both groups. The results of Independent Sample t-test on pre-test scores of experimental and control group students revealed that there was no significant difference in the pre-test scores of experimental and control group [t(22)=-.043; $\mathrm{p}>.05]$ which indicated that both groups were equal.

\subsection{Data Collection Tools}

In the current study, quantitative data were collected through the "Homophobia Scale" and qualitative data were collected through "semi-structured interviews". In addition, "Personal Information Form", which includes questions about gender, age, place of residence, sexual orientation, familiarity with homosexual individuals, has been used.

\subsubsection{The Homophobia Scale (HS)}

The scale was developed by Hudson and Ricketts (1980) and was adapted to Turkish by Sakallı and Uğurlu (2001). The Turkish form of the scale consists of 23 items. HS items consist of expressions about attitudes towards homosexual individuals and are rated using a six-point Likert-type rating scale. High scores from the scale indicate a high level of homophobia. In addition, by calculating the arithmetic average of the total score obtained from the scale, the participants can be divided into two groups according to their average score based on low and high homophobia levels. The Cronbach alfa coefficient was calculated for the original form and for 
the Turkish forms respectively as .90 and .94 (Hudson \& Ricketts, 1980; Sakallı \& Uğurlu, 2001).

\subsubsection{Semi-structured Interviews}

In this study, face-to-face interviews were conducted with psychological counselor candidates who have participated in the dealing with homophobia psycho-education program and interviews were recorded on a voice tape. Semi-structured interviews are made with the aim of obtaining the same kind of information from different people by focusing on similar topics (Patton, 1987). Semi-structured interview form is developed to ensure that all dimensions and questions related to the research problem are covered (Yıldırım \& Şimşek, 2013).

\subsection{Intervention Program}

The dealing with homophobia psycho-education program was developed by the researcher. The objectives of the program are raising awareness of psychological counselor candidates about attitudes and behaviors that include prejudice and discrimination towards homosexuals, helping them to develop intervention competence, communication skills and social skills with homosexual individuals. There are eight sessions in the program and each session is approximately two hours long. The content of the intervention program was summarized below.

In the first session, group members were introduced to each other and information was given about the group rules and the purpose and contents of the program. Then, the members were grouped into six pairs and were asked to the draw their partners picture and to make changes in their pictures if their partner was a homosexual individual. In addition, the concepts of sexual identity, sexual orientation, sexual role, lesbian, gay, bisexual, heterosexual and transsexual have been explained and that the members were encouraged to express their thoughts and feelings towards different sexual orientations and identities. At the beginning of the second session a short film entitled "Everyone is Different" was watched and the participants expressed the expressions or statements that they have heard about lesbian, gay, bisexual, and transsexual (LGBT) individuals. The source of these statements was discussed. Then, the concepts of stereotyping, prejudice, and discrimination were explained and these statements or expressions were discussed under these concepts. The members were asked to fill out a heterosexuality questionnaire to empathize with homosexual individuals and shared what they felt while responding to the questions. A short film entitled "Heterosexuals are answering the questions asked of the gays" was watched and the members were asked to watch the documentary film "My Child" as homework. The third session was started by sharing feelings and thoughts about the documentary film the members have watched as homework. Then the concepts of homophobia, biphobia, transphobia were discussed and theoretical explanations (behavioral, social learning and cognitive theory) of homophobia were explained. ABC model of cognitive therapy was used to explain the influence of thought on homophobia. Members were asked to write stereotypes, prejudices and discriminatory behaviors about LGBT, and these were addressed by the ABC model. A short film entitled "If the Earth spins reversed" was watched and to develop empathy with LGBT individuals and the feelings of the members were shared. Then, a game involving guessing homophobic expressions or statements was played, and members were asked to watch the movie "Tomboy" as homework. At the beginning of the fourth session feelings and thoughts of the members about the movie that they have watched as homework were shared. Then the members interacted with a lesbian and a gay individual invited to the session. Invited homosexual individuals described the process of recognizing their homosexual orientation and talked about the difficulties they have experienced, the psychological support they need in the school environment, and they have answered the questions of the group members. At the end of the session, the members were asked to watch the movie "Freedom to Love" as homework. In the fifth session, feelings and thoughts were shared about the film was first watched as homework. The members then interacted with a spiritual counselor who was invited to the session. The invited spiritual counselor made a presentation on the attitudes of different cultures and religions about homosexuality from past to present. The group members shared their feelings and thoughts about the influence of their religious beliefs and cultural values on their attitudes towards LGBT. The spiritual counselor responded to the questions of the group members in the framework of "empathic understanding, unconditional acceptance, and respect". At the end of the session, she was asked to watch the film "Danish Girl" as homework. At the beginning of the sixth session, feelings and thoughts were shared about the film that the members were watched as homework. Examples of homophobic discourses in our culture such as sexist idioms, idioms, proverbs were shared with the group members and the members are also asked to share this kind of homophobic discourse. Then each member is given a role that includes different races, genders, socioeconomic levels, sexual orientations, and they were asked to step forward or backward according to obtaining or not obtaining social rights. Thus, it is provided to understand the disadvantaged positions of the LGBT individuals in the society and the members were asked to watch the documentary film "Do not Look at Me" as homework. In the seventh session, feelings and thoughts were shared about the documentary film which was watched as homework. Later, several topics like difficulties that LGBT individuals experienced are in the school environment, the effects of 
peers and teachers' homophobic reactions, gender role expectations, and how these expectations limit their educational opportunities were discussed. How a psychological counselor can deal with homophobic attitudes and behaviors in school settings, how can they create a tolerant school climate, and how can they provide effective counseling services and psychological support were explained with examples. At the end of the session, the members were asked to watch the documentary film "Attention! Trans at School" as homework. In the eighth session, feelings and thoughts were shared about the documentary film that was watched as homework, and all the sessions were summarized. Then, all the members were invited to evaluate the sessions and outcomes and the processes of the intervention. They were asked to rate between one and ten the homophobia level before and after the program. They were also encouraged to share the activities that they found beneficial to reduce homophobia. Finally, the Homophobia Scale was applied and the program was terminated by giving a certificate of attendance to participants.

\subsection{Data Analysis}

In this study, a mixed research model (qualitative and quantitative research techniques) was used. In the analysis of quantitative data, the homogeneity of variance, kurtosis, and skewness of the distribution was calculated to determine whether the data were distributed normally, and the Shapiro-Wilks test was applied. The data obtained from the homogeneity test of variance indicated that there was no significant difference between the experimental and control groups in terms of homophobia scores ( $\mathrm{p}=.966, \mathrm{p}>.05)$, and groups were homogeneous. The kurtosis and skewness values for pre-test scores were calculated as -1.306 ( $\mathrm{SD}=.918)$ and -.261 ( $\mathrm{SD}=.472)$ respectively. If the coefficients of skewness and kurtosis are between +1 and -1 and are close to 0 and if the skewness and kurtosis indices which are calculated by dividing the skewness and kurtosis coefficients by their standard errors are between $+1,5$ and $-1,5$, the distribution can be accepted as normal (Tabachnick \& Fidell, 2013). Furthermore, the hypothesis that "the distribution of homophobia pre-test scores did not differ significantly from the normal distribution" was confirmed by the Shapiro-Wilks test ( $\mathrm{p}=.901, \mathrm{p}>.05)$. It is preferable to use the Shapiro-Wilks test when the sample size is smaller than 35 (Shapiro \& Wilk, 1965) and if the calculated $p$-value is larger than $\alpha=.05$ (Mertler \& Vannatta, 2005) it can be said that the data distributed normally. As a result of the normality test it was determined that the data has a normal distribution, thus parametric tests were used to analyze the data.

In order to determine the effectiveness of the program, The Two-Way Analysis of Variance (ANOVA) with Repeated Measures was used to compare the significance of differences pre-test, post-test and follow-up tests of participants in the experimental and control group. The Bonferroni test was applied to determine the source of variance and which of the means differ when significant differences were detected. The SPSS 21.0 for Windows package program was used for statistical analysis. The significance level was tested at $\mathrm{p}=.05$.

In the analysis of qualitative data, both participants and data collection tools are defined in as much detail as possible to verify the external reliability of the study. In order to provide internal validity, consistency was ensured in data collection, data analysis, and data interpretation processes. Descriptive methods were used to analyze and interpret the qualitative data on the effectiveness of the program. In this direction, first the voice recordings were transcribed; the answers of the participants were combined to create a qualitative data set and confirmed by an expert. A draft coding list has been formed by the researcher and the written data were coded by using the draft coding list. Possible themes were created during draft coding. After the certain themes and codes under those themes were defined by the researcher, a new coding system based on this theme-code relationship conducted by the researcher. Then the themes and codes were shared with another researcher, and inter-encoder reliability studies were carried out. The results of the reliability study demonstrated that all themes are reliable because the coding of each theme showed a value greater than .80. According to Miles and Huberman (1994), agreements between researchers must be at least $80 \%$ according to the inter-encoder reliability calculation. Both researchers came together to discuss codes, themes, and possible conflicts. Finally, the findings are organized and interpreted according to the themes.

\section{Results}

The mean pre-test, post-test and follow-up test scores and standard deviations of participants in the experimental group who attended the psycho-education program and control group who didn't attend the psycho-education program were given in Table 2. 
Table 2. The mean pre-test, post-test and follow-up test scores and standard deviations

\begin{tabular}{lllllll}
\hline Measurements & \multicolumn{2}{l}{ Pre-test } & \multicolumn{2}{c}{ Post-test } & \multicolumn{2}{c}{ Follow-up test } \\
\hline Groups & Mean & SD & Mean & SD & Mean & SD \\
\hline Experimental group $(\mathrm{n}=12)$ & 94.25 & 28.64 & 68.75 & 25.06 & 65.16 & 23.61 \\
Control group $(\mathrm{n}=12)$ & 94.75 & 28.05 & 98.33 & 31.25 & 92.16 & 29.94 \\
\hline
\end{tabular}

\subsection{The Effectiveness of Dealing with Homophobia Psycho-Education Program}

The mean homophobia pre-test, post-test and follow-up test scores and standard deviations of the participants in the experimental and control group are displayed in Table 2. Two-way repeated measure ANOVA was used to compare the difference between the mean scores of participants in the experimental and control groups. The results are presented in Table 3 .

Table 3. The results of Two-Way Repeated Measure ANOVA analysis

\begin{tabular}{llllll}
\hline Source & Sum of Square & Df & Mean Square & F & \\
\hline Between Groups & 54078.98 & 23 & & & \\
$\quad$ Group (Exp./Control) & 6517.014 & 1 & 6517.014 & 3.014 & .000 \\
$\quad$ Error & 47561.97 & 22 & 2161.908 & & \\
\hline Within Groups & 10028.67 & 48 & & & \\
$\quad$ Measurement (pre-test, post-test, follow-up) & 3156.361 & 2 & 1578.181 & 18.454 & .000 \\
$\quad$ Group*Measurement & $\mathbf{3 1 0 9 . 5 2 8}$ & $\mathbf{2}$ & $\mathbf{1 5 5 4 . 7 6 4}$ & $\mathbf{1 8 . 1 8 1}$ & $\mathbf{. 0 0 0}$ \\
$\quad$ Error & 3762.778 & 44 & 85.518 & & \\
\hline
\end{tabular}

As it can be seen in Table 3, results of the repeated measure analysis of variance applied to homophobia pre-test, post-test and follow-up scores of participants in experimental and control groups revealed that group effect was significant $(F(1-22)=3.014 ; \mathrm{p}<.001)$. Accordingly, it is seen that there is a significant difference between mean homophobia scores of participants in experimental and control groups, without distinction between pre-test, post-test and follow-up measures in each group.

It is also found that in both groups (without group difference) the difference between participants' mean pre-test, post-test and follow-up scores was significant $(\mathrm{F}(2-44)=18.454 ; \mathrm{p}<.001)$. These results indicated that when no group difference existed, dealing with homophobia psycho-education program has an impact on participants' homophobia level. In addition the value obtained as a result examining the common effect (group x measurement) was significant $(\mathrm{F}(2-44)=18.181 ; \mathrm{p}<.001)$. These findings indicate that the mean homophobia pre-test, post-test and follow-up test scores of psychological counselor candidates in experimental and control group have changed. The Bonferroni test was applied to determine the source of variance and which of the means differ when significant differences were detected. The results of the Bonferroni test are presented in Table 4.

Table 4. Bonferroni test results of mean scores of pre-test, post-test and follow-up test between groups and within groups

\begin{tabular}{|c|c|c|c|c|c|c|c|}
\hline & & \multicolumn{3}{|c|}{ Experimental group } & \multicolumn{3}{|c|}{ Control group } \\
\hline & & Pre-test & Post-test & Follow-up & Pre-test & Post-test & Follow-up \\
\hline \multirow{3}{*}{$\begin{array}{l}\text { Experimental } \\
\text { group }\end{array}$} & Pre-test & - & $25.50 * *$ & $29.08 * * *$ & .002 & & \\
\hline & Post-test & & - & 3.58 & & $6.55^{*}$ & \\
\hline & Follow-up & & & - & & & $6.02 *$ \\
\hline \multirow{3}{*}{ Control group } & Pre-test & & & & - & -3.58 & 2.58 \\
\hline & Post-test & & & & & - & 6.16 \\
\hline & Follow-up & & & & & & - \\
\hline
\end{tabular}

Table 4 indicates that there is a significant difference $\left(25.50^{* *}\right)$ between mean homophobia pre-test scores (94.25, SD=28.64) and mean homophobia post-test scores $(68.75, \mathrm{SD}=25.06)$ of participants in the experimental group. Additionally, a significant difference $\left(29.08^{* *}\right)$ was observed between mean homophobia pre-test scores (94.25, SD=28.64) and mean homophobia follow-up test scores $(65.16, \mathrm{SD}=23.61)$ of participants in the experimental group. On the other hand, it is found that the difference (3.58) between mean homophobia post-test scores $(68.75, \mathrm{SD}=25.06)$ and mean homophobia follow-up test scores $(65.16, \mathrm{SD}=23.61)$ of the participants in 
the experimental group is not significant. According to the results of the analysis given here, the homophobia level of psychological counselor candidates in experimental group has decreased and this decrement continued up to one month after the psycho-education program. Besides, a non-significant difference was obtained between mean homophobia pre-test $(94.75, \mathrm{SD}=28.05)$, post-test $(98.33, \mathrm{SD}=31.25)$ and follow-up test scores $(92.16$, $\mathrm{SD}=29.94$ ) of participants in the control group.

It was also found that there is a significant difference $\left(6.55^{*}\right)$ between mean homophobia post-test scores of psychological counselor candidates in the experimental group $(68.75, \mathrm{SD}=25.06)$ and control group (98.33, $\mathrm{SD}=31.25)$. Likewise, a significant difference was observed $\left(6.02^{*}\right)$ between mean homophobia follow-up scores of psychological counselor candidates in the experimental group $(65.16, \mathrm{SD}=23.61)$ and control group (92.16, $\mathrm{SD}=29.94)$. In other words, in comparison to participants in the control group, the homophobia level of psychological counselor candidates in experimental group who attended the dealing with homophobia psycho-education program, has decreased and this decrement continued up to one month after the psycho-education program.

\subsection{The Opinions of Psychological Counselor Candidates}

Provide dates defining the periods of recruitment and follow-up and the primary sources of the potential subjects, where appropriate. If these dates differ by group, provide the values for each group.

The content analysis was performed on the data obtained from the tape recordings of 12 interviews which the psychological counselor candidates have evaluated the effectiveness of the program. The obtained themes and subthemes were presented in Table 5.

Table 5. Obtained themes and subthemes

\begin{tabular}{lll}
\hline Theme & Subtheme & f \\
\hline The changes in attitudes & The changes in attitudes and behaviors related to LGBT people. & 12 \\
and behaviors after & The changes in defining basic concepts related to LGBT & 11 \\
the intervention & $\begin{array}{l}\text { The changes in opinions about participation of LGBT people in } \\
\text { professional life. }\end{array}$ & 10 \\
& The changes in attitudes to make social interactions with LGBT people & 12 \\
\hline Availability of the & Availability in professional life & 12 \\
acquired knowledge & Availability in daily life & 10 \\
\hline Useful activities in & Interaction with homosexual individuals & 12 \\
the intervention program & Meeting with a spiritual counselor & 10 \\
& Watching films and videos & 11 \\
& Sharing emotions and thoughts with group members & 10 \\
& Realistic enlightenment and activities & 9 \\
\hline Suggestions about the & Suggestions about the group process & 4 \\
effectiveness of the program & Suggestions about the number of sessions & 2 \\
& Suggestions about the content of the intervention program & 6 \\
\hline
\end{tabular}

As a result of the content analysis, 4 main themes were obtained as "the changes in attitudes and behaviors after the intervention", "the availability of the acquired information", "useful activities in the intervention program" and "the suggestions about the effectiveness of the program" (Table 5).

Four sub-themes have been defined within the main theme of "the changes in attitudes and behaviors after the intervention". The first subtheme is "the changes in attitudes and behaviors related to LGBT people" $(\mathrm{n}=12)$. According to findings obtained from participant interviews, it is seen that the opinions of participants about LGBT people have changed in a positive way. Participants stated that it has been understood that it is sexual orientation, not sexual preference, LGBT individuals are normal people as others, their negative thoughts about romantic relationships of LGBT people have decreased, their awareness on bullying that LGBT people exposed to have increased they have home empathetic, receptive and unconditionally respectful attitudes towards LGBT individuals. One of the psychological counselor candidates stated that;

"This was an issue that I didn't care about before. I was thinking that LGBT people are being excluded and exposed to bad things but that was all. While I was watching the videos about their life during the intervention, I realized that they didn't choose this. Especially, the story of a transsexual woman who had to be a sex worker because she couldn't find a job has impressed me very much. I had a strong idea that we mustn't exclude them. My negative thoughts towards LGBT people have changed a little bit in a 
positive way. If they exist then we have to accept them and learn to live together. My ideas have changed in that way."

The second sub-theme that has been defined within the main theme of "the changes in attitudes and behaviors after the intervention" is "the changes in defining basic concepts related to LGBT" $(\mathrm{n}=11)$. Within this theme, participants expressed their opinions that they can distinguish between the concepts of sexual orientation, sexual preference, and sexual identity, that they can use the definitions correctly. They also stated that their thoughts as homosexuality is an illness, disease or abnormal behavior have changed. One of the psychological counselor candidates expresses her ideas as follows:

"I have distinguished these concepts and use them more consciously. I noticed that I did not know the sexual identity. I think it was important to know the sexual identity to understand transsexuals. I realized the difference between sexual orientation sexual preferences. When we realize this difference, we don't see the person as responsible. Because I did not know these concepts before, I preferred not to talk. I see them as abnormal and absurd. I saw it as a different and absurd situation. Now I do not express exclusionary expressions. I'm trying to make correct explanations instead of not talking or excluding."

The third sub-theme that has been defined within the main theme of "the changes in attitudes and behaviors after the intervention" is "the changes in opinions about the participation of LGBT people in professional life" $(\mathrm{n}=10)$. Within this theme, the participants stated that LGBT individuals have to have equal rights in professional life as heterosexual individual, they should be able to choose the professions they want and to be able to work in any profession but not the ones that necessitate contacting with small children such as teachers, and their personal life should not adversely affect their professional life. One of the psychological counselor candidates stated that:

"Before the intervention program, I did not want them in professional life because I thought this was a preference. I would not want them as my child's teacher or doctor. But now I think that he/she may be my child's teacher or doctor as long as he/she does not negatively affect my child. They even need to be involved in professional life more. In the documentaries, I watched it was told that transsexual individuals have not had a lot of job opportunities, so they have to be sex workers or some of them committed suicide. That is a negative side. Human life is very valuable, so, they have to have equal rights in professional life."

The fourth sub-theme that has been defined within the main theme of "the changes in attitudes and behaviors after the intervention" is "the changes in attitudes to make social interactions with LGBT people" $(\mathrm{n}=12)$. Within this theme, participants reported that they would be able to make friends with LGBT individuals after the intervention, they would establish close relationships rather than a superficial communication and wouldn't have a negative view of them when they learn that a friend is LGBT. They also noted that sharing the same social environment and interacting with them may be entertaining. One of the psychological counselor candidates stated his/her opinion as follows:

"I have never had an LGBT friend before, there were only a few people I know. I talked about other subjects except for their sexual identities. I am not against them; I can even make friends. The homosexual guest speakers were very entertaining and friendly. I was hesitating while I was talking about a homosexual individual, and now I see that I can make friends with them."

Two sub-themes have been defined within the main theme of "availability of acquired knowledge". The first sub-theme is "availability in professional life" $(\mathrm{n}=12)$. Participants stated that they can use the information that they acquired in the program in their professional life, instead of referring the LGBT students they meet in their professional lives to the extent that they cannot help them adequately to another professional, they are more conscious and knowledgeable about how to behave and help them. They also have learned wrong interventions for LGBT students and how they can develop intervention programs to reduce negative attitudes of teachers towards LGBT students and to prevent peer bullying, they can have a healthy communication with LGBT students, show unconditional acceptance to them, demonstrate respect and be empathetic to them. One of the psychological counselor candidates stated his/her opinion as follows:

"For a school counselor, it is very likely to encounter with an LGBT student in professional life. If I had not attended this intervention program, I could have a fear when an LGBT student asked me for psychological help. I would not know what to do, I would inform the headmaster and the family. I could not help adequately because I did not know how to talk and behave toward him/her. Now I am more knowledgeable and conscious. I can be more understanding and tolerant of him/her. Now I know how to behave with these students." 
The second sub-theme that has been defined within the main theme of "availability of acquired knowledge" is "availability in daily life" ( $\mathrm{n}=10)$. The participants expressed that their opinions about the LGBT people have changed, they have more accepting attitudes towards diversity in daily life, and they are more respectful to different views, they can speak about LGBT more easily, they are more sensitive to the bullying that LGBT people exposed to, they can inform the family of LGBT individuals, and they are more interested in films about the LGBT. One of the psychological counselor candidates stated his/her opinion as follows:

"This was a field that I do not know and I was not interested in. I was informed of the murders in the news, but I did not think it was such a great injustice and exclusion, I was not wondering. Now I am more sensitive. Instead of ignoring people with different views, I realized that I try to understand them and their thoughts."

Five sub-themes have been defined within the main theme of "useful activities in the intervention program". The first sub-theme is "interaction with homosexual individuals" ( $\mathrm{n}=12)$. Participants stated that speaking with a gay or lesbian guest speaker has a positive impact on their awareness process about sexual orientations. In addition, the sharing of guest speakers' experiences about the difficulties that they face in professional life had an impact on participants" attitudes and that they perceived that they could make friends with homosexual individuals. One of the psychological counselor candidates stated his/her opinion as follows:

"A lesbian and a gay guest speaker came to a session. I've never met a lesbian or gay before. Thanks to this guest I had an opportunity to get to know better and to see that they are not different from us. I think this interaction was very helpful in reducing the negative attitudes."

The second sub-theme that has been defined within the main theme of "useful activities in the intervention program" is "meeting with a spiritual counselor" $(\mathrm{n}=10)$. Within this theme, the participants noted that their religious beliefs have a negative influence on their attitudes towards LGBT individuals, however, they don't have adequate knowledge about the views of religion about LGBT people. They also reported that they don't have adequate knowledge that how they can use the views of religion in the counseling process, so, meeting with the spiritual counselor was useful to meet their needs. One of the psychological counselor candidates stated his/her opinion as follows:

"I think my religious beliefs are influential in my negative attitudes. For this reason, the interview we had with the spiritual counselor was very influential. I have acquired true knowledge through this meeting. I realized that I ignored the tolerant approach of our religion. I am more moderate and accepting now."

The third sub-theme that has been defined within the main theme of "useful activities in the intervention program" is "watching films and videos" $(\mathrm{n}=11)$. Participants expressed that the films and videos that they watched during the program were well chosen, they were proper to the aim of the sessions, they were useful to know LGBT people well because the participants did not have enough opportunity to interact with them in real life and also the movies were helpful to be more sensitive to LGBT individuals. One of the psychological counselor candidates stated that;

"The movies and videos you have asked us to watch as homework at every session were very influential on me. Perhaps I was very reactive about this subject and the movies have provided me to be more sensitive."

The fourth sub-theme that has been defined within the main theme of "useful activities in the intervention program" is "sharing emotions and thoughts with group members" $(\mathrm{n}=10)$. Within this theme participants stated that they are able to share their opinions about LGBT without fear of being criticized by other group members in the group, they have the opportunity to learn different thoughts about this topic, $t$ this sharing helps them to feel good and contributes to the change of negative thoughts and feelings. One of the psychological counselor candidates stated his/her opinion as follows:

"In sessions, I was able to express my feelings and thoughts about LGBT individuals with ease. Without fear of criticism, everyone could share their feelings and thoughts in the group. It was nice to express myself. Thus, I noticed my wrong thoughts."

The fifth sub-theme that has been defined within the main theme of "useful activities in the intervention program" is "realistic enlightenments and activities" $(\mathrm{n}=9)$. Participants expressed that they need accurate information about LGBT, providing objective information is effective in reducing negative attitudes, group members can show active participation through some exercises and activities, and that these activities are both instructive and facilitative to develop empathy. One of the psychological counselor candidates stated that;

"The table on the board about LGBT was very instructive. Because it was a subject that I had never had 
any knowledge before. We have negative thoughts about things we do not have knowledge of. For this reason, giving objective information and realistic enlightenments were very influential. There were also some activities. Activities like drawing, showing empathy and evaluation schedules were both fun and enhanced my awareness."

Three sub-themes have been defined within the main theme of "suggestions about the effectiveness of the program". The first sub-theme is "suggestions about group process" $(\mathrm{n}=4)$. Within this theme, the participants have made suggestions for making contracts to ensure continuity of participation, increasing the active participation of the group members, watching some videos in the sessions which are required to be watched as homework, making home works and watching the films on time. One of the psychological counselor candidates stated his/her opinion as follows:

"There were some friends who were resistant to change their thoughts, and for this reason, I think they were absent. Some friends did not watch the movies and videos that you wanted to watch as homework on time, so they could not participate in sharing. A contract could be made in the first session or pre-session to clarify expectations such as participation and making home works on time."

The second sub-theme that has been defined within the main theme of "suggestions about the effectiveness of the program" is "suggestions about the number of sessions" $(\mathrm{n}=2)$. Within this theme, participants stated that the duration of the sessions is long, the session duration can be shortened and the number of sessions can be increased. One of the psychological counselor candidates stated his/her opinion as follows:

"Some of the sessions took a very long time and we have lost our attention. It may be better if the session length is shortened and the number of sessions increases."

The third sub-theme that has been defined within the main theme of "suggestions about the effectiveness of the program" is "suggestions about the content of the intervention program" $(\mathrm{n}=6)$. Within this theme, participants suggested to invite the family members of LGBT person and a transsexual individual and a homosexual couple to the sessions, to interact with a LGBT individual in daily life, to ask the group members to investigate contradictory views that they have as homework and to add more entertaining activities to the content of the program. One of the psychological counselor candidates stated his/her opinion as follows:

"The group members could be asked to investigate contradictory views that they have as homework and defend and discuss these views in the group. We were able to visit environments that could interact with homosexual individuals. Because as long as we meet them, we more consciously aware thoughts. One-to-one communication is more effective to change negative of thoughts."

\section{Discussion}

Due to the low acceptance by society and the negative experiences that they face in schools, LGBT students are under the risk of social isolation (Henderson, 2016), school absenteeism (Burton et al., 2014); substance use (Tait, 2015); depression (Dunn et al., 2015); suicidal thoughts or attempts (Bouris et al., 2016). LGBT individuals need psychological counseling because of these problems they are experiencing, but they state that they are not satisfied with psychological counseling because they keep their sexual orientation hidden from the counselor. The main reason for this is that counselors are not informed about homosexuality and have negative attitudes towards homosexuality (Vural-Batık, 2018). So that, it is thought that psychological counselors' attitudes and behavior towards homosexuality need to be changed.

In this study, an intervention program to reduce the levels of homophobia of psychological counselor candidates was developed and the effectiveness of the program was examined. As a result, it has been determined that the dealing with Homophobia psycho-education program has an effect in reducing the level of homophobia and this effect is also permanent. Similar to this finding, studies with university students (Ben-Ari, 1998; Case \& Stewart, 2010; Chang, 2002; Chonody, Siebert, \& Rutledge, 2009; Cooley \& Burkholder, 2011; Foreman \& Quinlan, 2008; Kelley et al., 2008; Nelson \& Krieger, 1997; Sakall, 2002a; Sakallı \& Uğurlu, 2001, 2003), teachers and teacher candidates (Ollis, 2010; Riggs et al., 2011), mental health professionals and candidates of mental health professionals (Engberg et al., 2005; Rudolph, 1989) indicated that interventions program have an effect in reducing the negative attitudes towards homosexuality. In some of these studies the effect of informing about sexuality, in some other studies, the effect of interacting with homosexual individuals and in some studies the effect of both interacting with homosexual individuals and informing about sexuality were investigated.

In the studies that that proved the effectiveness of giving information about homosexuality to reduce the negative attitudes toward homosexuality (Foreman \& Quinlan, 2008; Higgins et al., 2001; Ollis, 2010; Riggs et al., 2011; Waterman, Reid, Garfield, \& Hoy, 2001) it was seen that the duration of the program varies from one hour to six 
hours, the content of the program contains the concept of diversity, the concepts of sexual orientation, lesbian, gay, bisexual, and transsexual have been explained and information about sexual minorities' problems has been revealed. In their study, Foreman and Quinlan (2008) have examined the effect of training on social workers' awareness of homophobia and their attitudes toward LGBT. In the 2-3-hour training session, basic information about LGBT was given, small group activities were done, LGBT related topics were discussed, attitudes, experiences, needs, fears, and myths related to the topic were determined through role-playing technique and participants shared their thoughts about the movies they watched. Home-work such as reading a gay or lesbian magazine, responding to homophobic jokes, holding a homosexual man's hand were given. It was determined that participants do have positive feedback on the content of training, and they are pleased to be able to discuss LGBT issues in a safe and open environment and the training is effective to help participants discover their attitudes, values, and prejudices towards LGBT individuals. Likewise, in the current study, it is thought that providing objective information about LGBT, sexual orientation and gender identity reduces the negative attitudes towards homosexuality. As a matter of fact, participants' opinion confirms this. Most of the participants stated that the information provided in the training was effective in changing the negative attitudes.

Another method that is effective in changing attitudes towards homosexual individuals is interacting with these individuals (Herek, 2000). In studies which examined the effect of interacting with homosexual individuals (Chang, 2002; Cooley \& Burkholder, 2011; Engberg et al., 2005; Nelson \& Krieger, 1997; Sakall, 2002a; Sakallı \& Uğurlu, 2001) it has been found that the negative attitudes toward homosexuality have decreased. In a study by Nelson and Krieger (1997), a panel of university students was organized by their homosexual peers. In the panel first, homosexual guests described themselves, their past, the process of recognizing their feelings about sexual experiences and their sexual orientation, and then answered the questions about the reactions of their parents and friends and their experiences in the face of negative reactions. Findings demonstrated that the negative attitudes towards homosexuality decreased significantly. In the current research, it is thought that interacting with both a gay and lesbian person, sharing of homosexual individuals about the difficulties they experienced ant the duration of the interaction which was 3 hours were effective to reduce the negative attitudes. It is also seen that participants' opinions are in this direction. In addition, participants have made suggestions for giving homework on interacting with homosexual individuals in daily life.

It is expected that the change in attitudes will be more effective in establishing interaction after information rather than just information or interaction (Anthony, 1972). It is thought that, in the current program, providing objective information has changed the thoughts about homosexuality and interaction has changed the feelings towards homosexual individuals. Indeed, it is seen that many studies on reducing negative attitudes towards homosexuality (Ben-Ari, 1998; Case \& Stewart, 2010; Chonody et al., 2009; Kelley et al., 2008) intervention programs involve both giving information and interaction. In a study (Case \& Stewart, 2010) it was aimed to examine the effectiveness of a training as a part of an undergraduate course about diversity. In addition to theoretical knowledge, a panel was organized with a panel with a lesbian and a transsexual woman and university students interacted with them. At the end of the semester, the prejudice level of students who attended the course towards homosexuals decreased significantly and there was no significant difference in the students who did not attend the course. The presentation format of the panel is very important to change the attitudes. In order for the panel to be effective, it is recommended that panelists should interact with audiences rather than making a monologue presentation. However, the similarities between the panelist and the audiences and being a peer with the audiences are also influential (Chng \& Moore, 1991). In this study, it is seen that the participants are satisfied with the interaction with homosexual individuals even though they do not peer and don't have a similar status with the homosexual individuals they interact with. On the other hand, it can be suggested that to choose homosexual individuals with similar ages and status who the students will interact may be more effective.

When the content of the interventions to reduce homophobia is examined it has been seen that in addition to giving information, organizing panel and interaction the intervention programs involves watching videos and movies related to LGBT (Ben-Ari, 1998, Cooley \& Burkholder, 2011, Foreman \& Quinlan, 2008, Higgins et al. , 2015; Kağnıc1, 2015; Riggs et al., 2011). The videos and films to help participants to witness the stories of LGBT individuals and interact with them through media (Cooley \& Burkholder, 2011). Similarly, in the current study, the majority of the participants stated that watching video or film as a homework each week was effective. They also suggested inviting the families of LGBT individuals to the session. For this reason, it is considered important to interview with families to understand the difficulties of families of LGBT individuals in the intervention programs aimed at reducing the level of homophobia.

In the current study, the result that the dealing with homophobia psycho-education program has a positive effect on psychological counselor candidates, is thought to contribute to the field. Psychological counselors may play 
an important role not only in preventing peer violence but also in making interventions to reduce teachers' homophobic attitudes. Because teachers' negative attitudes towards sexual minorities have a negative effect on the school life of these students (Chesir-Tehran, 2003, Kosciw \& Diaz, 2006, Mudrey \& Medina-Adams, 2003). Teachers are expected to understand and deal with the cultural diversity in their classes, including sexual diversity (Szalacha, 2004). Teachers should be trained in the knowledge and skills required to support LGBT students in their classroom (Riggs et al., 2011). Although in Turkey, undergraduate programs on teacher education include different courses about diversity, it is observed that these courses don't address sexual diversity. Therefore, psychological counselors may play an important role in teachers' in-service training in schools. For all these reasons, it is important to make interventions to reduce the level of homophobia of psychological counselors.

It is important that undergraduate program in counseling and guidance should involve courses about sexual diversity and homophobia in order for psychological counselors to develop accepting attitudes towards LGBT individuals (Ummak \& Gündoğdu, 2014). In this direction, it is suggested that in courses about diversity teaching staff may assign experiential home works, invite homosexual speakers, make audiovisual presentations and to make animations to help to help students to develop empathy in order to reduce prejudice towards LGBT individuals (Battle, 2004; Nelson \& Krieger, 1997). It is recommended that the courses in the undergraduate program of psychological counseling and guidance should be examined and designed on the basis of multicultural counseling. According to Buhrke and Douce (1991), who recommended that undergraduate programs in psychological counseling should be reformed, information about the homosexual individuals, the prevalence of homosexuality, myths and stereotypes can be given in the introduction to psychology courses within the topics of individual differences, different groups, and cultural minorities. In the theories of counseling and psychotherapy course, while discussing traditional counseling approaches and theories of human development, it may be mentioned that these approaches and theories have been developed in a heterosexual framework and theoretical approaches about the identity development of homosexual individuals may be addressed. In group counseling courses, while task-oriented groups are discussed, lesbian and gay support groups can also be mentioned. In career counseling courses, specific issues related to homosexual individuals, whether a profession supports homosexuals and whether their sexual orientation influences their education. In practice courses, the students can be provided to make counseling practices through role-playing to understands the problems that the LGBT individuals face and then to make counseling with a homosexual individual. It will also be useful to have social interaction with LGBT individuals in their undergraduate education so that psychological counselors can develop acceptable attitudes towards LGBT individuals (Engberg et al., 2005). These interventions not only change the attitudes of psychological counselors towards LGBT individuals, but they can also increase their professional competence (Rudolph, 1989). Likewise, in this study, psychological counselor candidates stated that their self-efficacy beliefs on making psychological counseling with LGBT students and developing interventions programs for teachers and peers have increased.

In short, the American Counseling Association Code of Ethics (ACA, 2014) require that psychological counselors should be aware of diversity and sensitive to needs of minority groups. For this reason, psychological counselors should be familiar with and sensitive to the problems of LGBT individuals (Buhrke \& Douce, 1991). Their attitudes towards LGBT individuals should not be negative. Therefore, it is thought that dealing with homophobia psycho-education program that developed in this research will meet a great need in the field.

\section{References}

ACA (American Counseling Association). (2014). American Counseling Association Code of Ethics. Stevenson Avenue Alexandria, VA. https://doi.org/10.1002/9781119221548.ch7

Anthony, W. (1972). Societal rehabilitation: Changing society's attitudes toward the physically and mentally disabled. Rehabilitation Psychology, 19, 117-126. https://doi.org/10.1037/h0090877

Ben-Ari, A. T. (1998). An experiential attitude change. Journal of Homosexuality, 36(2), 59-71. https://doi.org/10.1300/J082v36n02_05

Battle, C. L. (2004). Promoting increased understanding of sexual diversity through experiential learning. Teaching of Psychology, 31, 118-120.

Bostwick, W. B., Boyd, C. J., Hughes, T. L., \& McCabe, S. E. (2010). Dimensions of sexual orientation and the prevalence of mood and anxiety disorders in the United States. American Journal of Public Health, 100, 468-475. https://doi.org/10.2105/AJPH.2008.152942

Bouris, A., Everett, B. G., Heath, R. D., Elsaesser, C. E., \& Neilands, T. B. (2016). Effects of victimization and 
violence on suicidal ideation and behaviors among sexual minority and heterosexual adolescents. $L G B T$ Health, 3, 153-161. https://doi.org/10.1089/lgbt.2015.0037

Budak, S. (2003). Psikoloji sözlüğ̈̈ (2. Ed.), Ankara: Bilim ve Sanat Yayınları.

Buhrke, R. S., \& Douce, L. A. (1991). Training issues for counseling psychologists in working with lesbian women and gay men. The Counseling Psychologist, 19(2), 216-234. https://doi.org/10.1177/0011000091192006

Burton, C. M., Marshal, M. P., \& Chisolm, D. J. (2014). School absenteeism and mental health among sexual minority youth and heterosexual youth. Journal of School Psychology, 52, 37-47. https://doi.org/10.1016/j.jsp.2013.12.001

Butler, J. (2010). Queer yoldaşlığı ve savaş karşıtı siyaset. Queer forum içinde (s. 19-28). V. Uluslararası Homofobi Karşıtı Buluşma, Ankara.

Button, D. M., O'Connell, D. J., \& Gealt, R. (2012). Sexual minority youth victimization and social support: The intersection of sexuality, gender, race, and victimization. Journal of Homosexuality, 59, 18-43. https://doi.org/10.1080/00918369.2011.614903

Case, K. A., \& Stewart, B. (2010). Changes in diversity course student prejudice and attitudes toward heterosexual privilege and gay marriage. Teaching of Psychology, 37, 172-177. https://doi.org/10.1080/00986283.2010.488555

Chang, M. (2002). The impact of an undergraduate diversity course requirement on students' racial views and attitudes. The Journal of General Education, 51(1), 21-42. https://doi.org/10.1353/jge.2002.0002

Chesir-Tehran, D. (2003). Conceptualizing and assessing heterosexism in high schools: a setting-level approach. American Journal of Community Psychology, 31(3/4), 267-280. https://doi.org/10.1023/A:1023910820994

Chng, C. L., \& Moore, A. (1991). Can attitudes of college students toward AIDS and homosexuality be changed in six weeks? The effects of a gay panel. Health Values, 15, 41-49.

Chonody, J. M., Siebert, D. C., \& Rutledge, S. E. (2009). College students' attitudes toward gays and lesbians. Journal of Social Work Education, 45(3), 499-512. https://doi.org/10.5175/JSWE.2009.200800002

Cohen, L., Manion, L., \& Morrison, K. (2000). Research methods in education. (5. Ed.), London: Routledge Falmer.

Cooley, J. J., \& Burkholder, G. J. (2011). Using video and contact to change attitudes toward gay men and lesbians. Journal of Social, Behavioral, and Health Sciences, 5(1), 83-90.

Dunn, H. K., Clark, M. A., \& Pearlman, D. N. (2015). The relationship between sexual history, bullying victimization, and poor mental health outcomes among heterosexual and sexual minority high school students: A feminist perspective. Journal of Interpersonal Violence, 32(22), 3497-3519. https://doi.org/10.1177/0886260515599658

Elipe, P., de la Oliva Muñoz, M., \& Del Rey, R. (2018) Homophobic bullying and cyberbullying: study of a silenced problem. Journal of Homosexuality, 65(5), 672-686. https://doi.org/10.1080/00918369.2017.1333809

Engberg, M. E. Hurtado, S., \& Smith, G. C. (2007). Developing attitudes of acceptance toward lesbian, gay, and bisexual peers: Enlightenment, contact, and the college experience. Journal of Gay \& Lesbian Issues in Education, 4(3), 49-77. https://doi.org/10.1300/J367v04n03_05

Ferfolja, T. (2008). Discourses that silence: Teachers and anti-lesbian harassment. Studies in the Cultural Politics of Education, 29(1), 107-119. https://doi.org/10.1080/01596300701802805

Foreman, M., \& Quinlan, M. (2008). Increasing social work students' awareness of heterosexism and homophobia- A partnership between a community gay health project and a school of social work. Social Work Education, 27(2), 152-158. https://doi.org/10.1080/02615470701709485

Gegenfurtner, A., \& Gebhardt, M. (2017). Sexuality education including lesbian, gay, bisexual, and transgender (LGBT) issues in schools. Educational Research Review, 22, 215-222. https://doi.org/10.1016/j.edurev.2017.10.002

GLSEN (Gay, Lesbian, and Straight Education Network) (1999). Homophobia 101: Teaching respect for all. Retrieved from http://www.glsen.org/binary-data/GLSEN_ATTACHMENTS/file/96-1.pdf

Guasp, A. (2009). Homophobic bullying in Britain's schools: The teachers' report Stonewall (Ed.), Research 
Reports. Retrieved from http://www.stonewall.org.uk/at_school/education_for_all/quick_links/education_resources/4003.asp

Henderson, M. (2016). Bullying experiences among sexual minority youths in England: The nature, prevalence and association with life satisfaction. Journal of Research in Gender Studies, 6, 220-240. https://doi.org/10.22381/JRGS6120167

Herek, G. (2000). The psychology of sexual prejudice. Current Directions in Psychological Science, 9, 19-22. https://doi.org/10.1111/1467-8721.00051

Higgins, D., King, R., \& Witthaus, D. (2001). Pride and Prejudice: Facilitating change in the attitudes of students towards gay men and lesbians. Health Promotion Journal of Australia, 12(3), 238-241.

Hudson, W., \& Ricketts, W. (1980). A strategy for measurement of homophobia. Journal of Homosexuality, 5, 357-372. https://doi.org/10.1300/J082v05n04_02

Kağnıcı, D. Y. (2015). Psikolojik danışman eğitiminde cinsel yönelim olgusunun irdelenmesi: Benim Çocuğum filmi. Türk Psikolojik Danışma ve Rehberlik Dergisi, 5(44), 83-95.

Kaysen, D. L., Kulesza, M., Balsam, K. F., Rhew, I. C., Blayney, J. A., ... Lehavot, K. (2014). Coping as a mediator of internalized homophobia and psychological distress among young adult sexual minority women. Psychology of Sexual Orientation and Gender Diversity, 1(83), 225-233. https://doi.org/10.1037/sgd0000045

Kelley, L., Chou, C. L., Dibble, S. L., \& Robertson, P. A. (2008). A critical intervention in lesbian, gay, bisexual, and transgender health: Knowledge and attitude outcomes among second-year medical students. Teaching and Learning in Medicine, 20(3), 248-253. https://doi.org/10.1080/10401330802199567

Kosciw, J. G., \& Diaz, E. M. (2006). The 2005 national school climate survey: The experiences of lesbian, gay, bisexual, and transgender youth in our nation's schools. New York: GLSEN.

Mertler, C. A., \& Vannatta, R. A. (2005). Advanced and multivariate statistical methods: Practical application and interpretation (3. Ed.), United States: Pyrczak Publishing.

Meydan-Acımış, N., \& Tekindal, M. A. (2013). Eğitim fakültesi öğrencilerinin Hudson ve Ricketts tutum ölçeğine göre cinsel yönelimlere bakışı. Sted, 23(2), 38-45.

Miles, M, B., \& Huberman, A. M. (1994). Qualitative data analysis: An expanded Sourcebook. (2. Ed.), Thousand Oaks, CA: Sage.

Mudrey, R., \& Medina-Adams, A. (2003). Attitudes, perceptions, and knowledge of pre-service teachers regarding the educational isolation of sexual minority youth. Journal of Homosexuality, 51(4), 63-90. https://doi.org/10.1300/J082v51n04_04

Murdock, T. B., \& Bolch, M. B. (2005). Risk and protective factors for poor school adjustment in lesbian, gay, and bisexual (LGB) high school youth: variable and person-centered analysis. Psychology in the Schools, 42(2), 159-172. https://doi.org/10.1002/pits.20054

Nelson, E. S., \& Krieger, S. L. (1997). Changes in Attitudes toward homosexuality in college students. Journal of Homosexuality, 33(2), 63-81. https://doi.org/10.1300/J082v33n02_04

Ollis, D. (2010). 'I haven't changed bigots but ...': Reflections on the impact of teacher professional learning in sexuality education. Sex Education, 10(2), 217-230. https://doi.org/10.1080/14681811003666523

Orue, I., \& Calvete, E. (2018). Homophobic bullying in schools: The Role of homophobic attitudes and exposure to homophobic aggression. School Psychology Review, 47(19), 95-105. https://doi.org/10.17105/SPR-2017-0063.V47-1

Patton, M. O. (1987). How to use qualitative methods in evaluation. Newbury Park, CS: Sage.

Riggs, A. D., Rosenthal, A. R., \& Smith-Bonahue, T. (2011). The impact of a combined cognitive affective intervention on pre-service teachers' attitudes, knowledge, and anticipated professional behaviors regarding homosexuality and gay and lesbian issues. Teaching and Teacher Education, 27, 201-209. https://doi.org/10.1016/j.tate.2010.08.002

Rudolph, J. (1989). Effects of a workshop on mental health practitioners' attitudes toward homosexuality and counseling effectiveness. Journal of Counseling \& Development, 68, 81-85. https://doi.org/10.1002/j.1556-6676.1989.tb02499.x

Sakalli, N. (2002a). The relationship between sexism and attitudes toward homosexuality in a sample of Turkish 
college students. Journal of Homosexuality, 42, 51-62. https://doi.org/10.1300/J082v42n03_04

Sakall, N. (2002b). Application of the attribution-value model of prejudice to homosexuality. Journal of Social Psychology, 142, 264-271. https://doi.org/10.1080/00224540209603899

Sakallı, N., \& Uğurlu, O. (2001). Effects of social contact with homosexuals on heterosexual Turkish University students' attitudes toward homosexuality. Journal of Homosexuality, 42(1), 53-62. https://doi.org/10.1300/J082v42n01_03

Sakallı, N., \& Uğurlu, O. (2003) The effects of social contact with a lesbian person on the attitude change toward homosexuality in Turkey. Journal of Homosexuality, 44(1), 111-119. https://doi.org/10.1300/J082v44n01_06

Santona, A., \& Tognasso, G. (2018). Attitudes toward homosexuality in adolescence: An Italian study. Journal of Homosexualty, 65(3), 361-378. https://doi.org/10.1080/00918369.2017.1320165

Saraç, L. (2012). Attitudes of future physical education teachers in Turkey toward lesbians and gay men. Psychological Reports, 111(3), 765-775. https://doi.org/10.2466/11.06.21.PR0.111.6.765-775

Sargin, N., \& Circir, O. (2015). The attitudes of prospective teachers toward homosexuality: A case study in Konya. International Journal of Psychology and Educational Studies, 1(1), 17-24. https://doi.org/10.17220/ijpes.2015.01.004

Selek, P. (2003). Ataerkillik ve eşcinsellere yönelik şiddet. Lezbiyen ve Geylerin Sorunları ve Toplumsal Barış İçin Çözüm Arayışları Sempozyumu, Mayıs, Ankara.

Shapiro, S. S., \& Wilk, M. B. (1965). An analysis of variance test for normality (Complete samples). Biometrika, 52(3/4), 591-611. https://doi.org/10.1093/biomet/52.3-4.591

Szalacha, L. A. (2004). Educating teachers on LGBTQ issues: A review of research and program evaluations. Journal of Gay \& Lesbian Issues in Education, 1(4), 67-79. https://doi.org/10.1300/J367v01n04_07

Tabachnick, B. G., \& Fidell, L. S. (2013). Using multivariate statistics (6. Ed.). United States: Pearson Education.

Tait, R. J. (2015). Alcohol-related victimisation: Differences between sexual minorities and heterosexuals in an Australian national sample. Drug and Alcohol Review, 34, 366-374. https://doi.org/10.1111/dar.12265

Thatcher, W. G., \& Chandler, S. (2013). Heterosexual attitudes towards homosexuality. An exploratory study of college student perceptions. College Student Affairs Journal, 31(1), 27-39.

TPA (Turkish Psychiatric Association). (2015). TPD ve CETAD ortak basın açıklaması: Cinsellik çok boyutludur. Retrieved from http://www.psikiyatri.org.tr/presses.aspx?press=427\&type=24

Ummak, E. (2012). Mersin Üniversitesi öğrencilerinin eşcinsellere yönelik tutumlarının incelenmesi. Yayınlanmamış yüksek lisans tezi, Mersin Üniversitesi Eğitim Bilimleri Enstitüsü, Mersin.

Ummak, E. (2016). Homofobiyle baş etme grup rehberliği programına ilişkin deneysel bir çalışma. Yayınlanmamış doktora tezi, Çukurova Üniversitesi Sosyal Bilimler Enstitüsü, Adana.

Ummak, E., \& Gündoğdu, M. (2014). Rehber öğretmenlerin eşcinsellere yönelik psikolojik danışma konusundaki bilgileri. 1. Avrasya Ĕgitim Araştırmaları Kongresi, İstanbul.

Vural-Batık, M. (2018). Psikolojik danışman adaylarının homofobi düzeyleri. V. ASM International Congress of Social Science, 5-7 Mayıs, Antalya.

Waterman, A. D., Reid, J. D., Garfield, L. D., \& Hoy, S. J. (2001). From curiosity to care: Heterosexual student interest in sexual diversity courses. Teaching of Psychology, 28, 21-26. https://doi.org/10.1207/S15328023TOP2801_05

Yıldırım, A., \& Şimşek, H. (2013). Sosyal bilimlerde nitel araştırma yöntemleri (9. Ed.). Ankara: Seçkin yay.

Yüksel, Ş. (2010). Eşcinsellik, sosyal dışlanma ve ruh sağlığı sorunlarına yaklaşım. Hastalık'tan ideolojiye homofobi içinde (s. 79-83). V. Uluslararası Homofobi Karşıtı Buluşma, Ankara.

\section{Copyrights}

Copyright for this article is retained by the author(s), with first publication rights granted to the journal.

This is an open-access article distributed under the terms and conditions of the Creative Commons Attribution license (http://creativecommons.org/licenses/by/4.0/). 